\title{
Assessment of the Changing Pattern in Maize Cultivation in Sokoto-Rima River Basin, Nigeria
}

\author{
ADEJUWON, J O \\ Department of Water Resources Management and Agrometeorology, Federal University of Agriculture Abeokuta, Nigeria \\ Email:adejoseph2003@yahoo.com
}

\begin{abstract}
Maize, a monocotyledonous crop, grown for grain and forage, is the most important cereal crop in sub-Saharan Africa. This study assessed the changing pattern in maize cultivation in Sokoto-Rima River Basin, Nigeria. Questionnaire was administered to 450 respondents from 15 agricultural settlements in 15 local governments in the study area, using clustered sampling technique. Data was analyzed using frequency counts, percentage and pairwise ttest. Results showed that 20 maize varieties exist in the basin. Ten of the twelve varieties planted in 1970's are still being cultivated, two varieties no longer exist while 8 varieties were newly introduced at the time of this investigation. Yellow maize known as 'Ja Masara' (40.19\%) was the most popular variety in the 1970's. This was closely followed by white maize called 'Fari Masara' (39.57\%). These two varieties still accounted for over 70\% in 2000's, with white maize accounting for $46.76 \%$. The cultivation of yellow maize decreased by $13.43 \%$ while white maize increased by $7.19 \%$. Yellow maize known as project variety 'Yar Project' $(8.73 \%)$ is a new variety that is gaining popularity among the farmers. The pairwise t-test result showed no significant difference between the past and present varieties planted. The factors that determine choice of the varieties cultivated include resistance to pests and diseases, personal preference, yield, the period of maturity and resistance to drought. The cultivation maize in the Basin haves increased by $7.19 \%$ over time from $71.7 \%$ to $78.89 \%$.
\end{abstract}

\section{DOI: https://dx.doi.org/10.4314/jasem.v22i9.12}

Copyright: Copyright $@ 2018$ Adejuwon. This is an open access article distributed under the Creative Commons Attribution License (CCL), which permits unrestricted use, distribution, and reproduction in any medium, provided the original work is properly cited.

Dates: Received: 09 July 2018; Revised: 28 August 2018; Accepted: 30 August 2018

Keywords: maize varieties, changing pattern, Sokoto-Rima River Basin

Maize (Zea Mays) originates in the Balsas River Valley of south-central Mexico in Central America where it was domesticated by indigenous people about 10,000 years ago, dispersed into lower Central America by $5600 \mathrm{BC}$ and had moved into the interAndean valleys of Colombia between 5000-4000 BC (Piperno, 2011; Kennett et al,, 2015). It was introduced into Guinea and the Congo in Africa by the Portuguese in the 1500's and has since become one of African's dominant food crops (McCann, 2001; International Institute of Tropical Agriculture (IITA), 2009). Maize is an annual plant, serving for only one growing season prior to harvest and can reach 2-3 meters in height. There are about 50 different species of maize having their own characteristic features and kernel sizes, all belonging to a small number of types. Colour and structure, as well as the shape of the kernel, differ from one species to another.

White, red and yellow are the most common basic colours of maize, but it is possible to find a wide range of shades, from red-brown to light red and from a pale yellow to orange. Among several cereal crop varieties, maize is cultivated globally, being one of the most important cereal crops worldwide. Maize is the most important cereal crop in sub-Saharan Africa (SSA) occupying more than 33 million ha each year and an important staple food for more than 1.2 billion people in SSA and Latin America (IITA, 2009; FAOSTAT, 2015). More than 300 million people in SSA depend on maize as a source of livelihood. The worldwide production of maize is $1,048,610,000$ metric tons in 2014 (statista, 2016; World Atlas, 2016). Regional average yields are $1.7 \mathrm{t} / \mathrm{ha}$ in West Africa and $1.5 \mathrm{t} / \mathrm{ha}$ in East Africa, and $1.1 \mathrm{t} / \mathrm{ha}$ in Southern Africa (Smale et al., 2011). The United States of America, the worldwide leader in maize production with 377.5 million metric tonnes of maize (World Atlas, 2016) and $36 \%$ of the world total in 2014 (Statista, 2016), has been leading in maize production over time. The world ranking of maize production shows Nigeria as the 12th largest producer of maize in 2012 with 8,694,900 tonnes, 14th largest producer in 2013 with 8,422,670 tonnes (FAOSTAT, 2015) and 14th largest producer in 2014 with 10,790,600 tonnes (Knoema, 2016). In Africa, Nigeria is positioned second behind South Africa which ranked 12th, 11th and 10th in the world in 2012, 2013 and 2014, with 11,830,000 tonnes, $12,486,000$ tonnes and 15.5 million tonnes respectively (FAOSTAT, 2015; World Atlas, 2016). 
Nigeria production decreased by $2.07 \%$ in 2012 and $3.13 \%$ in 2013 but increased by $28.11 \%$ in 2014 . The top 20 countries, namely South Africa, Nigeria, Ethiopia, Tanzania, Malawi, Kenya, Zambia, Uganda, Ghana, Mozambique, Cameroon, Mali, Burkina Faso, Benin, DRC, Angola, Zimbabwe, Togo, and Cote d'Ivoire, account for $96 \%$ of the total maize production in SSA (FAOSTAT, 2015).

This study is necessitated by the fact that no research has been carried out on the changing pattern in the choice of cereal varieties (maize) in Sokoto-Rima River Basin, Nigeria. This study intends to fill the gap created by lack of literature in the study area. The study aimed at assessing the changing pattern in tomato cultivation in Sokoto-Rima River Basin, Nigeria.

\section{MATERIALS AND METHODS}

The Study Area: The study area, Sokoto-Rima River Basin lies between Latitude $10.8^{\circ} \mathrm{N}$ and $13.58^{\circ} \mathrm{N}$ and longitude $3.30^{\circ} \mathrm{E}$ and $7.13^{\circ} \mathrm{E}$ (Figure 1). It exhibits a tropical climate, with a definite and marked wet and dry season while the tropical maritime air mass dominates the entire basin during the rainy season, whereas the tropical continental (cT) air mass predominates during the dry season.

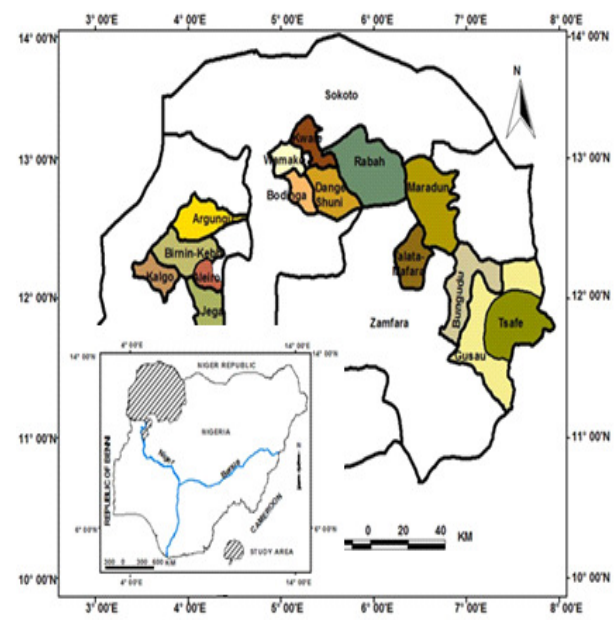

Fig 1: Selected Local Governments Areas where questionnaire were administered in Sokoto-Rima River Basin, Nigeria

The wet season is between May and September in the southern part and June to October in the north (Adejuwon, 2015). The rainfall pattern in SokotoRima Basin is a good reflection of the seasonal variation of the surface location of the inter-tropical discontinuity (ITD); the rainfall is single maxima in character. Annual rainfall amount varies from about $650 \mathrm{~mm}$ in the northern part to about $1013 \mathrm{~mm}$ in the southern part (Adejuwon, 2012) and the rainfall decreases in both duration and amount from the south northward. High humidity reaching an average of $80 \%$ in the southern area is experienced in the wet season and lower humidity of about $30 \%$ in the dry season (Emielu, 2000). Humidity decreases to a mean value of 20 or $25 \%$ in January and April while diurnal values may fall from $50 \%$ at dawn to $10 \%$ in the afternoon, which is characteristic of the Harmattan when the dry and dust-laden North East trade winds are blowing from the Sahara under cloudless but dusty conditions. This period is marked with very cold temperatures and dust-laden winds often accompanied by a thick fog of alarming intensity. The mean annual temperature is $34.5^{\circ} \mathrm{C}$ (Adejuwon, 2015). The highest temperatures are normally in hot season of March to April while the minimum temperatures are usually recorded in January to February.

Data Collection, Sampling and Analysis: Primary data was employed in this study. Clustered sampling technique was used for administration of questionnaire in 2009. Five agricultural settlements from five Local Governments each from 3 zones of Sokoto, Kebbi and Zamfara were selected for this study (Table 1). Thirty copies of research questionnaires were administered in each settlement, making a total of four hundred and fifty. Data were analysed using frequency counts, percentages and pairwise t-test. A pairwise t-test was used to examine the difference in maize varieties between the past and the present.

Table 1: The states, local governments and communities where

\begin{tabular}{|l|l|l|}
\hline data were sourced in Sokoto-Rima River Basin \\
\hline State & $\begin{array}{l}\text { Local } \\
\text { Government }\end{array}$ & Communities \\
\hline Sokoto & Wamakko & Gumbi \\
& Bodinga & Mil Goma \\
& Kware & Durbawa \\
& Dange Shuni & Dange \\
& Rabah & Maikujera \\
\hline Kebbi & Kalgo & Kalgo \\
& Birni-Kebbi & Gulumbe \\
& Aliero & Dakala \\
& Jega & Basaura \\
& Argungu & Alwasa \\
\hline Zamfara & Talata & Tunfafiya \\
& Mafara & Madidi \\
& Gusau & Dosara \\
& Maradun & Tazame \\
& Bungudu & Tsafe \\
& Tsafe & \\
\hline
\end{tabular}

\section{RESULT AND DISCUSSION}

Twenty varieties of maize are cultivated in SokotoRima River Basin. Ten of the twelve varieties planted in 1970's are still being cultivated in 2000's, two varieties no longer exist while 8 varieties were newly introduced (Table 2). Yellow maize known as 'Ja Masara' $(40.19 \%)$ was the most popular variety in the 1970 's. This was closely followed by white maize 
called 'Fari Masara' (39.57\%). These two varieties accounted for $79.76 \%$ in 1970's and still made-up of over $70 \%$ in 2000's, with white maize accounting for $46.76 \%$. Though, the two varieties were the most popular, the preference for the varieties has changed tremendously. The cultivation of yellow maize decreased by $13.43 \%$ while white maize increased by $7.19 \%$ (Table 3). White maize has gained more popularity and acceptability among farmers, and is presently about half of the maize planted. Generally, farmers cultivating maize has increased by $7.19 \%$ over time. Farmers that planted maize in the 1970's in the Basin were $71.7 \%$ while $78.89 \%$ cultivated it in 2000's. Report has shown that a larger area is planted to white than to yellow maize in the tropical highland and subtropical/mid-latitude environments in the developing world, and it occupies about 40 percent of the lowland tropical maize area. More than 90 percent of the white maize is produced in the developing countries, where it accounts for around one-quarter of total maize output and just under two-fifth of the total maize area (FAO, 1995; Heisey and Mwangi, 1996). Despite the reduction in the planting of yellow maize, it is the second most popular and accounts for over a quarter of the maize varieties planted in Sokoto-Rima River Basin. The reason for this could have been the recent realisation of the advantages of yellow maize. Yellow maize contains vitamin A, while white maize does not (Muzhingi et al., 2011; Shah et al., 2016). Although this vitamin can make a contribution to human nutrition, the amount of the vitamin present in yellow maize is insufficient to meet a significant portion of human requirements.

Table 2: Maize varieties planted in Sokoto-Rima River Basin

\begin{tabular}{|c|c|c|c|c|}
\hline \multirow[t]{2}{*}{ Varieties } & \multicolumn{2}{|c|}{ Planted in 1970's } & \multicolumn{2}{|c|}{ Planted in 2000's } \\
\hline & $\begin{array}{l}\text { Number of } \\
\text { respondents }\end{array}$ & $\%$ & $\begin{array}{l}\text { Number of } \\
\text { respondents }\end{array}$ & $(\%)$ \\
\hline Ja Masara (Yellow maize) & 129 & 40.19 & 95 & 26.76 \\
\hline Fari Masara (White maize) & 127 & 39.57 & 166 & 46.76 \\
\hline Baselma & 2 & 0.62 & 2 & 0.56 \\
\hline Bahausha & 8 & 2.49 & 3 & 0.85 \\
\hline Yargoru - Ja (Yellow Yargoru) & 38 & 11.84 & 5 & 1.41 \\
\hline Yargoru - Fari (White Yargoru) & 4 & 1.25 & 12 & 3.38 \\
\hline Yar Neja - Ja (Yellow Yar Neja) & 1 & 0.31 & 3 & 0.85 \\
\hline Yar Neja - Fari (White Yar Neja) & 1 & 0.31 & 1 & 0.28 \\
\hline `Agwado - Gajere (short Agwado) & 1 & 0.31 & 1 & 0.28 \\
\hline Yar Bauchi & 1 & 0.31 & 2 & 0.56 \\
\hline Gajere - Ja (Short yellow) & 7 & 2.18 & - & - \\
\hline Kanana & 2 & 0.62 & - & - \\
\hline Doguwa - Ja (Yellow Doguwa) & - & - & 16 & 4.51 \\
\hline Doguwa -Fari (White Doguwa) & - & - & 10 & 2.82 \\
\hline Arniya & - & - & 3 & 0.85 \\
\hline $\begin{array}{l}\text { Ja Masara Yar Project (Project } \\
\text { Yellow maize) - }\end{array}$ & - & - & 31 & 8.73 \\
\hline Yar Zahi (Zahi variety) & - & & 1 & 0.28 \\
\hline Cross Breed & - & - & 2 & 0.56 \\
\hline Ja (Yellow)- 2 to 3 Comb & - & - & 1 & 0.28 \\
\hline Fari (White)- 2 to 3 Comb & - & - & 1 & 0.28 \\
\hline Total & 321 & 100 & 355 & 100 \\
\hline
\end{tabular}

Yellow maize is favored in livestock feeding since it gives poultry meat, animal fat and egg yolk the yellow colour valued by consumers in many countries. Yellow maize is used for the manufacture of fuel alcohol and high fructose sugar (Peralta-Contreras et al., 2014). Therefore, there may be a shift towards yellow maize than white in recent years in Africa and other areas where white maize is leading. According to Lopez-Pereira and Morris (1994), the trends suggest that the increased preference in the developing world for the use of maize as livestock feed may be shifting emphases somewhat in breeding towards yellow maize. Apart from yellow maize and white maize, yellow Yargoru (11.84\%) planted in the 1970's and Project yellow maize (Yar Project-Ja) (8.73\%) planted in 2000's were also famous among the farmers in the basin. However, white Yargoru, yellow Doguwa and white Doguwa varieties were planted by few farmers. Other varieties cultivated in the basin have not gained much recognition among farmers. as they were cultivated by less than $8 \%$ of the farmers. The new varieties planted in the Basin accounted for $18.71 \%$, with Project yellow maize (Yar Project) $(8.73 \%)$ and yellow Doguwa $(4.51 \%)$ leading other varieties. The choice of maize varieties cultivated is determined by personal preference, yield, taste, appearance, the period of maturity, resistance to pests and diseases, resistance to drought among others. The cultivation of improved varieties such as yellow maize (2 to 3 Comb), white maize (2 to 3 Comb), Project Yellow maize variety (Yar Project) and Crossbreed varieties were due to resistance to pests and diseases, resistance 
to drought, yield and the period of maturity. Yakubu and Yakubu (2008) noted that farmers in the Basin cultivated early maturing varieties as a displacement to local varieties. Anderson and Hazell (1987) argued that adoption of common high-yielding varieties, uniform planting practices, and common timing of field operations have caused yields of many crops to become more strongly influenced by weather patterns, especially in developing countries. IITA developed drought-tolerant maize varieties that are adapted to the Guinea and Sudan savanna of West Africa (IITA, 2004). In some African countries, yields of white maize are generally higher than those of yellow. Byerlee and Heisey (1997) observed that country yields are more variable for African than for Latin American or Asian countries for all maize, at any given yield level.

Table 3: Differences in the percentage of farmers' planting maize varieties in Sokoto-Rima River Basin

\begin{tabular}{|l|l|l|l|}
\hline Varieties & $\begin{array}{l}\text { Percentage of } \\
\text { farmers' in 1970's }\end{array}$ & $\begin{array}{l}\text { Percentage of } \\
\text { farmers' in 2000's }\end{array}$ & $\begin{array}{l}\text { Difference } \\
\text { (\%) }\end{array}$ \\
\hline Ja Masara (Yellow maize) & 40.19 & 26.76 & 13.43 \\
\hline Fari Masara (White maize) & 39.57 & 46.76 & -7.19 \\
\hline Baselma & 0.62 & 0.56 & 0.06 \\
\hline Bahausha & 2.49 & 0.85 & 1.64 \\
\hline Yargoru - Ja (Yellow Yargoru) & 11.84 & 1.41 & 10.43 \\
\hline Yargoru - Fari (White Yargoru) & 1.25 & 3.38 & -2.13 \\
\hline Yar Neja - Ja (Yellow Neja variety) & 0.31 & 0.85 & -0.54 \\
\hline Yar Neja - Fari (White Neja variety) & 0.31 & 0.28 & -0.03 \\
\hline 'Agwado - Gajere (short Agwado) & 0.31 & 0.28 & -0.03 \\
\hline Yar Bauchi & 0.31 & 0.56 & -0.03 \\
\hline Gajere- Ja (Short yellow) & 2.18 & - & - \\
\hline Kanana & 0.62 & - & - \\
\hline Doguwa - Ja (Yellow Doguwa) & - & 4.51 & - \\
\hline Doguwa -Fari (White Doguwa) & - & 2.82 & - \\
\hline Arniya & - & 0.85 & - \\
\hline Ja Masara Yar Project (Project Yellow maize) & - & 8.73 & - \\
\hline Yar Zahi (Zahi variety) & & 0.28 & - \\
\hline Cross Breed & - & 0.56 & - \\
\hline Ja (Yellow)- 2 to 3 Comb & - & 0.28 & - \\
\hline Fari (White)- 2 to 3 Comb & - & 0.28 & - \\
\hline
\end{tabular}

The t-test result of the difference in maize varieties between 1970's and 2000' is as follows: $\mathrm{t}(19)=-0.95$, $\mathrm{p} \geq 0.05, \mathrm{CI}_{0.95}-12.99,4.89$ (Table 4). This means there is no significant difference between the past and present varieties as observed during the study period. Seed varieties, financial outlays, environmental factors and influences including soil fertility management, moisture stress, weeds, plant density and pests and diseases also affects the yield of maize (Seran and Brintha, 2010; Reynolds et al., 2015; $\mathrm{Xu}, 2016)$. Soil fertility management is probably the most important crop management problem in developing countries. Weed control and plant density management are also important management problem in developing country maize production. The insects of maize include European corn borer (Ostrinia nubilalis) (ECB), Fall armyworm (Spodoptera frugiperda), Corn earworm/Cotton bollworm (Helicoverpa Zea) and so on. The susceptibility of maize to the European corn borer and corn rootworms and the resulting large crop losses are estimated at a billion dollars worldwide for each pest (Ostlie, et al., 2008; Marra et al., 2012). Maize diseases include Corn smut (Ustilago maydis), Maize dwarf mosaic virus, Maize streak virus and so on. Abebe et al (2009) evaluated commonly used maize varieties, against the maize weevil Sitophilus zeamais Motsch, one of the most important cosmopolitan stored product pests in maize and recommended 'BHQP-542' variety as a resistant varieties out of 13 improved varieties studied in managing $\mathrm{S}$. zeamais in stored maize under subsistence farming conditions in Africa.

Conclusion: This study has shown that yellow maize was the most popular variety in the 1970's, closely followed by white maize but in 2000', white maize was the most widely cultivated. The cultivation of yellow maize decreased by $13.43 \%$ while white maize increased by $7.19 \%$. Project yellow maize variety gained more popularity than other new varieties. The study has also shown no significant difference between the past and present varieties planted. The cultivation of maize in the Basin has increased by $7.19 \%$ over time.

\section{REFERENCES}

Abebe, F; Tefera, T; Mugo, S; Beyene, Y; Vidal, S (2009). The resistance of maize varieties to the maize weevil Sitophilus zeamais (Motsch) (Coleoptera: Curculionidae). African Journal of Biotechnology 8(21): 5937-5943 
Adejuwon, JO (2012). An Assessment of the Effect of Climate Variability on Selected Agricultural Practices and Yields in Sokoto-Rima River Basin, Nigeria. Unpublished $\mathrm{PhD}$ Thesis, Obafemi Awolowo University, Ile-Ife, p. 312

Adejuwon, JO (2015). An assessment of the changing pattern in the choice of vegetable varieties in SokotoRima River Basin, Nigeria: Pepper. Int. J. Ecol. Env. Studies, 3(2): 7-15.

Anderson, JR; Hazell, PBR (1987). Variability in corn yields: Implications for agricultural research and policy in developing countries, Published for The International Food Policy Research Institute-Baltimore and London: The John Hopkins University Press.

Byerlee, D; Heisey, PW (1997). Evolution of the African Maize Economy. In D. Byerlee and C.K. Eicher (eds.), Africa's Emerging Maize Revolution. Boulder, Colorado: Lynne Rienner Publishers.

Food and Agriculture Organization of the United Nations (1995). White Maize as a Traditional Staple Food: Situations, Outlook and Issues. 26 th $^{\text {th }}$ Session of the Intergovernmental Group on Grains. $30^{\text {th }}$ May-2 June

FAO (2015). Crop Water Information: Maize. Food and Agriculture Organization Water Development and Management unit. www.fao.org/nr/water/cropinfo_maize.html

FAOSTAT (2015). Crop Production. Food and Agriculture Organization, Statistics section. http://faostat3.fao.org/browse/Q/*/E

Heisey, PW; Mwangi, W (1996). Fertilizer Use and Maize Production in Sub-Saharan Africa. CIMMYT Economics Program Working Paper 96-01. Mexico, D.F.: CIMMYT.

International Institute of Tropical Agriculture - IITA (2004). Annual Report for 2004. Ibadan, Nigeria.

International Institute of Tropical Agriculture - IITA (2009). Maize. www.iita.org/maize

Kennett, DJ; Thakar, HB; Van Derwarker, AM; Webster, DL; Culleton, BJ; Harper, TK; Hirth, K (2017). Highprecision chronology for Central American maize diversification from El Gigante rockshelter, Honduras. Proceedings of the National Academy of Sciences of the United States of America, 114(34): 9026-9031.

Knoema (2016). Nigeria - Crops Production » Quantity (tonnes) - Maize. World Data Atlas. https://knoema.com/atlas/Nigeria/topics/Agriculture/C rops-Production-Quantity-tonnes/Maize

Marra, MC; Piggott, NE; Goodwin, BK (2012). The impact of corn rootworm protected biotechnology traits in the United States. AgBioForum 15 (2): 217-230.
McCann, J (2001). Maize and grace. Comparative Studies in Society and History 43, no. 2: 246-72. doi: $10.1017 /$ S0010417501003486

Muzhingi, T; Gadaga, TH; Siwela, AH; Grusak, MA; Russell, RM; Tang, G (2011). Yellow maize with high $\beta$-carotene is an effective source of vitamin $A$ in healthy Zimbabwean men. The American Journal of Clinical Nutrition, 94 (2), 510-519.

Ostlie, KR; Hutchison, WD; Hellmich, RL (2008). Bt Corn and European Long-Term success through resistance management. University of Minnesota Extension Office

Peralta-Contreras, M; Aguilar-Zamarripa, E; Pérez-Carrillo, E; Escamilla-García, E; Serna- Saldívar, SO (2014). Ethanol Production from Extruded Thermoplastic Maize Meal by High Gravity Fermentation with Zymomonas mobilis, Biotechnology Research International, vol. 2014, Article ID 654853, 8 pages, 2004.

Piperno, DR (2011). The Origins of Plant Cultivation and Domestication in the New World Tropics: Patterns, Process, and New Developments. Current Anthropology, 52(S4), S453-S470.

Reynolds, TM; Waddington, SR; Anderson, CL; Chew, A; True, Z; Cullen, A (2015). Environmental impacts and constraints associated with the production of major food crops in Sub-Saharan Africa and South Asia. Food Security, 7(4): 795-822

Seran, TH; Brintha, I (2010). Review on Maize Based Intercropping, J. Agronomy, 9 (3): 135145

Shah, TR; Prasad, K; Kumar, P; Yildiz, F (2016). MaizeA potential source of human nutrition and health: A review, Cogent Food and Agriculture, 2:1,

Statista (2016). Distribution of global corn production in 2015, by country. www.statista.com/market/

World Atlas (2016). World Leaders in Corn (Maize) Production, By Country. 2016 worldatlas.com

Yakubu, M; Yakubu, A (2008). Effect of Climate Change on Livelihood in Sokoto State. In: Chinedum Nwajiuba (ed). Climate Change and Adaptation, Hohenheim, M Margraf Verlag, 145-154.

Xu, Y (2016). Envirotyping for deciphering environmental impacts on crop plants. TAG. Theoretical and Applied Genetics. Theoretische Und Angewandte Genetik, 129, 653-673. 